\title{
The influence of the menstrual cycle on the result of brain examination with hydrogen magnetic resonance spectroscopy - a pilot study
}

\section{Wpływ cyklu miesięcznego na wynik badania mózgu za pomoca spektroskopii protonowej rezonansu magnetycznego - badanie pilotowe}

\author{
Robert Chrzan', Monika Tomaszuk², Andrzej Urbanik' \\ 'Department of Radiology, Collegium Medicum, Jagiellonian University, Krakow, Poland \\ 2 Department of Endocrinology, Collegium Medicum, Jagiellonian University, Krakow, Poland
}

Neurologia i Neurochirurgia Polska 2013; 47, 5: 450-455

DOI: 10.5114/ninp.2013.38224

\begin{abstract}
Background and purpose: Hydrogen magnetic resonance spectroscopy ( $\left.{ }^{1} \mathrm{HMRS}\right)$ is nowadays one of the basic tools for noninvasive brain metabolism assessment. The study focuses on the important problem of the influence of hormone fluctuation during the menstrual cycle on brain metabolism, assessed by ${ }^{1} \mathrm{HMRS}$ for clinical diagnostics.

Material and methods: In 11 healthy regularly menstruating women, ${ }^{1} \mathrm{HMRS}$ was performed at the start (phase I), in the middle (phase II) and at the end (phase III) of the menstrual cycle. The relative concentration ratios of 12 brain metabolites in every woman in all cycle phases were examined, in 6 different volumes of interest (VOIs). Finally, statistically significant differences in relative metabolite ratios between the phases examined in given locations were sought.

Results: Statistically significant relations between menstrual cycle phases and relative ratios of 4 metabolites $-\mathrm{Lac} / \mathrm{Cr}$, $\mathrm{NAA} / \mathrm{Cr}$, Glx1/Cr and Glx2/Cr - in different brain locations were found. In all locations, mean $\mathrm{NAA} / \mathrm{Cr}$ ratios were greater in phase I compared to the other phases. A similar relationship was found for $\mathrm{Glx} 1 / \mathrm{Cr}$ ratio in one location (left occipital lobe). For $\mathrm{Lac} / \mathrm{Cr}$ and $\mathrm{Glx} 2 / \mathrm{Cr}$ ratios, a higher mean ratio value was obtained in phase II compared to phases I and III in the right occipital lobe and left basal ganglia, respectively.
\end{abstract}

\section{Streszczenie}

Wstęp i cel pracy: Spektroskopia protonowa rezonansu magnetycznego ( $\left.{ }^{1} \mathrm{HMRS}\right)$ jest obecnie jednym z podstawowych narzędzi nieinwazyjnej oceny metabolizmu mózgu. Praca dotyczy istotnego problemu wpływu zmian hormonalnych w trakcie cyklu miesięcznego na metabolizm mózgu, oceniany dla celów diagnostyki klinicznej za pomocą ${ }^{1} \mathrm{HMRS}$.

Materiał i metody: U 11 zdrowych, regularnie miesiączkujących kobiet wykonano badanie ${ }^{1} \mathrm{HMRS}$ na początku (faza I), w środku (faza II) i na końcu (faza III) cyklu miesięcznego. U każdej z kobiet we wszystkich powyższych fazach oceniano względne stężenia 12 metabolitów mózgu w 6 różnych obszarach zainteresowania (VOI). Dla każdej lokalizacji poszukiwano istotnych statystycznie różnic we względnych stężeniach metabolitów w poszczególnych fazach cyklu.

Wyniki: Stwierdzono istotne statystycznie zależności między fazą cyklu miesięcznego a względnymi stężeniami 4 metabolitów: $\mathrm{Lac} / \mathrm{Cr}, \mathrm{NAA} / \mathrm{Cr}$, Glx1/Cr oraz $\mathrm{Glx} 2 / \mathrm{Cr}$ w różnych lokalizacjach. We wszystkich lokalizacjach stężenia NAA/Cr były większe w fazie I w porównaniu $\mathrm{z}$ pozostałymi fazami. Podobną zależność zaobserwowano dla stężenia Glx1/Cr w jednej lokalizacji (lewy płat potyliczny), natomiast dla stężeń $\mathrm{Lac} / \mathrm{Cr}$ i Glx2/Cr, odpowiednio w prawym płacie potylicznym i lewych jądrach podstawy, stwierdzono większe wartości w fazie II w porównaniu $z$ fazami I i III.

Correspondence address: Robert Chrzan, Department of Radiology, Collegium Medicum, Jagiellonian University, Kopernika 19, $31-501$ Krakow, Poland, phone: + 481242473 91, fax: +48 1242473 90, e-mail: rchrzan@mp.pl

Received: 11.10.2012; accepted: 7.01.2013 
Conclusions: Menstrual cycle phase should be considered in planning a date and interpretation of ${ }^{1} \mathrm{HMRS}$ examination, performed for the verification of a disease manifesting as brain metabolite disturbances in the ${ }^{1} \mathrm{HMRS}$ spectrum.

Key words: menstrual cycle, brain metabolism, ${ }^{1} \mathrm{HMRS}$.

\section{Background and purpose}

According to the World Health Organization (WHO) definition, the menstrual cycle is a term for cyclical changes in a woman's body under the influence of fluctuating levels of hormones of the hypothalamichypophyseal-ovarian axis - hypothalamus, pituitary gland, ovaries - from menarche to the last menstruation before menopause [1].

Previous papers in the field of gynecological endocrinology concerning the female hormonal system, the physiology of the menstrual cycle and its disturbances, as well as diseases resulting from improper functioning of the linked gland system, present mutual relationships between the glands and their products relatively precisely, starting from central nervous system functions and ending at ovarian activity $[1,2]$. The reverse direction, that is, menstrual cycle impact on brain functions, has not been precisely analyzed till now. However, it was found that the cycle significantly influences the central nervous system [3-8].

The technique enabling in vivo assessment of biochemical composition of tissues in selected brain locations is hydrogen magnetic resonance spectroscopy ( $\left.{ }^{1} \mathrm{HMRS}\right)$. In spite of a very limited set of metabolites available for in vivo measurement, nowadays this method is coming to be seen as one of the main imaging tools for brain metabolism assessment [9-16].

Until now, only a few papers concerning this issue have been presented and no systematic research has been undertaken, including comparison of the broad set of metabolites identified in brain ${ }^{1}$ HMRS of healthy women in various locations and during different menstrual cycle phases [17-21].

It seems important to know all the physiological processes, including the menstrual cycle, affecting the natural variability of ${ }^{1} \mathrm{HMRS}$ spectra obtained by commonly available $1.5 \mathrm{~T}$ magnetic resonance (MR) systems, because investigation of this issue is important for the analysis of ${ }^{1} \mathrm{HMRS}$ spectra used to differentiate physiological and pathological processes [10-12].
Wnioski: Faza cyklu miesięcznego powinna być uwzględniana przy wyznaczaniu daty $\mathrm{i}$ interpretacji badania ${ }^{1} \mathrm{HMRS}$ przeprowadzanego w celu weryfikacji choroby manifestującej się zaburzeniami poziomów metabolitów mózgu w widmie ${ }^{1}$ HMRS.

Słowa kluczowe: cykl miesięczny, metabolizm mózgu, ${ }^{1}$ HMRS.

This study, therefore, focuses on the influence of hormonal fluctuation during the menstrual cycle on brain metabolism. The detection of possible relationships between brain metabolite changes and the menstrual cycle phases ought to be an important element to consider during ${ }^{1} \mathrm{HMRS}$ assessment for clinical diagnostics. Additionally, the results obtained may be a valuable data source in extending knowledge in the field of gynecological endocrinology.

\section{Material and methods}

The material comprised 11 healthy regularly menstruating women. The women were taking no hormonal drugs, including contraceptives. In all subjects, neurological or psychiatric disorders and brain trauma in history were excluded. Average age was $24.3 \pm 3.8$ years (22 to 29 years).

All women were non-smokers and, for 24 hours prior to the examinations, they were not allowed to drink alcohol to avoid the impact of smoking and alcohol on brain metabolite levels [20,22-26].

The study was accepted by the local bioethical committee. Informed consent was obtained from all the patients in the study after the nature of the procedure had been fully explained.

Women were examined three times: (a) at the start of the menstrual cycle (first to fifth cycle day - phase I), (b) in the middle of the menstrual cycle (13 th to $16^{\text {th }}$ cycle day - phase II), (c) at the end of the menstrual cycle (25 th to $28^{\text {th }}$ cycle day - phase III).

Examinations were performed using the MR Signa Excite $1.5 \mathrm{~T}$ system and data were processed using the SAGE software (GE Healthcare).

Each woman was placed in the supine position with her head inside the sending/receiving coil. To properly locate the volumes of interest (VOIs), T2-weighted axial localizers were first obtained (TE $88.2 \mathrm{~ms}$, TR $4000.0 \mathrm{~ms}$, slice width $5 \mathrm{~mm}$, gap $0 \mathrm{~mm}$ ).

Single-voxel spectroscopy (SVS) was used in the procedure. Six brain VOIs were selected in the following 


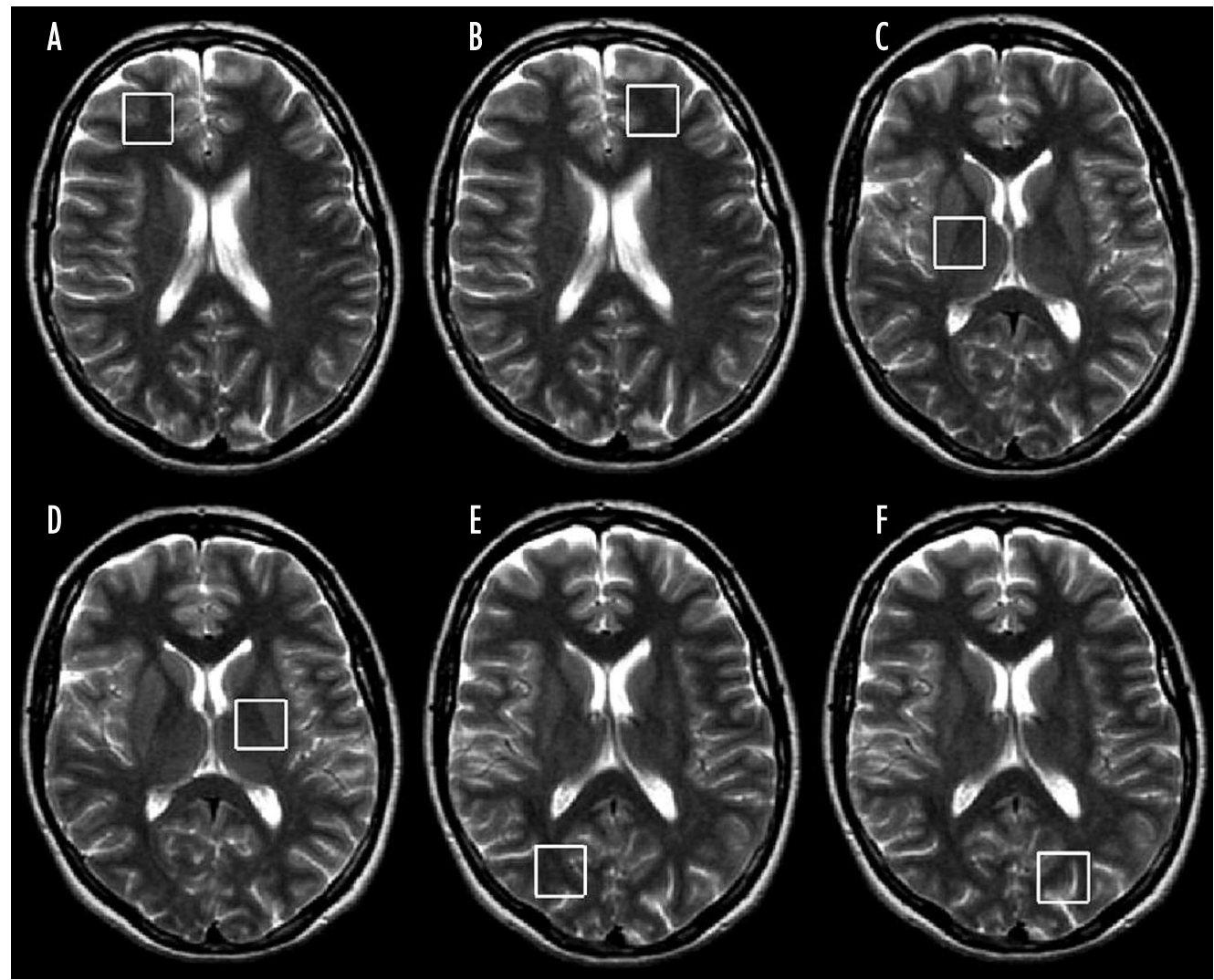

Fig. 1. VOI locations: A) right frontal lobe, B) left frontal lobe, C) right basal ganglia, D) left basal ganglia, E) right occipital lobe, F) left occipital lobe

regions: right (VOI1) and left (VOI2) frontal lobe, right (VOI3) and left (VOI4) basal ganglia, right (VOI5) and left (VOI6) occipital lobe (Fig. 1).

The same parameters were used in all examinations at all time points: VOI volume $8 \mathrm{~cm}^{3}$ (voxel $\left.2 \times 2 \times 2 \mathrm{~cm}\right)$, imaging sequence PROBE-P (PROton Brain Exam) (TE $35 \mathrm{~ms}$, TR $1500 \mathrm{~ms}$, single VOI measurement time $2.12 \mathrm{~s}, \mathrm{NEX} 8.0$, flip angle $90^{\circ}$, FOV $24 \times 24$ ).

After data processing, results were obtained in the form of values representing the area below the metabolite peak for a given VOI and cycle phase. Abbreviations and locations of metabolite peaks in the spectrum using ppm units are presented in Table 1.

Then, relative concentration ratios for every metabolite level in every woman in all cycle phases examined were compared. Distribution normality analysis was performed using the Shapiro-Wilk test and homogeneity of variance by the Levene test. For the final statistical assessment of results, a one-way analysis of variance with repeated measurements was selected, and the examination phase was used as a grouping variable. Relative metabolite concentration ratios from single locations, two locations combined (VOI1 + VOI2, VOI3 + VOI4, VOI5 + VOI6), three locations combined (VOI1 + $+\mathrm{VOI} 3+\mathrm{VOI} 5, \mathrm{VOI} 2+\mathrm{VOI} 4+\mathrm{VOI} 6)$ and all locations combined (VOI1 + VOI2 + VOI3 + + VOI4 + VOI5 + VOI6) were analyzed.

If a statistically significant difference of metabolite ratios between the phases examined in a given location was obtained, then the Tukey post-hoc test was used to find the source of variability. A confidence level of $95 \%$ $(\alpha=0.05)$ was used in all the tests.

\section{Results}

Statistically significant results were obtained for 4 of the 12 metabolites examined: $\mathrm{Lac} / \mathrm{Cr}, \mathrm{NAA} / \mathrm{Cr}$, Glx1/Cr and $\mathrm{Gl} 2 / \mathrm{Cr}$ (Table 2 ). For the $\mathrm{NAA} / \mathrm{Cr}$ ratio, a statistically significant difference was found not only for a single VOI1 (the right frontal lobe), but also for multiple ones including VOI1 + VOI2 (both the frontal lobes), VOI1 + VOI3 + VOI5 (the right hemisphere), and all locations combined (the whole brain). Mean NAA/Cr ratios 
were greater in phase I corresponding to menstruation compared to the other phases. A similar relationship was found for the Glx1/Cr ratio in one location, VOI6 (the left occipital lobe). For the $\mathrm{Lac} / \mathrm{Cr}$ and $\mathrm{Glx} 2 / \mathrm{Cr}$ ratios respectively in VOI5 (the right occipital lobe) and VOI4 (the left basal ganglia) locations, a higher mean ratio value was obtained in phase II, representing ovulation, compared to phases I and III (late luteal phase).

Above all, the results represent NAA level changes during the menstrual cycle. It is believed that statistically significant results obtained for NAA/Cr in VOI1 and VOI combinations including VOI1 result from the variability of this metabolite mainly in the frontal lobes, particularly in the right one.

\section{Discussion}

The mammalian brain presents great structural and functional plasticity under the influence of both external and internal factors. The classic example is the specific feedback between brain and gonads observed during the menstrual cycle in women [27]. Research has shown diverse brain work during the menstrual cycle which is a demonstration of the influence of the female gonads on brain metabolism.
Table 1. Metabolites assessed in the study

\begin{tabular}{|lcc|}
\hline Metabolite & $\begin{array}{c}\text { Peak location } \\
\text { (ppm) }\end{array}$ & Abbreviation \\
\hline Free lipids & $0.90-1.10$ & Lip \\
\hline Lactate & 1.33 & Lac \\
\hline$N$-acetylaspartate & 2.02 & NAA \\
\hline Glutamine + glutamate & $2.10-2.20$ & Glx1 \\
& 2.45 & Glx2 \\
& $3.60-3.80$ & Glx3 \\
\hline$\gamma$-aminobutyric acid & 2.30 & GABA \\
\hline Creatine and phosphocreatine & 3.02 & Cr \\
\hline Choline & 3.22 & Cho \\
\hline Glucose & 3.43 & Glc1 \\
& 3.80 & Glc2 \\
\hline Myoinositol & 3.56 & mI \\
\hline
\end{tabular}

The greatest variability during the cycle was found in the NAA/Cr ratio, mainly in frontal lobe locations. NAA is called a neuronal marker. It is recognized as a marker of axonal density and vitality - a decrease in the NAA level correlates with a loss of neurons or func-

Table 2. Statistically significant results $(p<0.05)$ - mean values of a given metabolite ratio in a selected phase are represented by Roman numerals*

\begin{tabular}{|c|c|c|c|c|}
\hline Metabolit & Location & Mean \pm SD & & Tukey post-hoc test \\
\hline $\mathrm{Lac} / \mathrm{Cr}$ & VOI5 & $\begin{aligned} \text { Phase I } & =0.207 \pm 0.085 \\
\text { Phase II } & =0.262 \pm 0.085 \\
\text { Phase III } & =0.166 \pm 0.073\end{aligned}$ & $\begin{array}{c}\mathrm{F}(2,20)=3.992 \\
\quad(p=0.035)\end{array}$ & Phase II > Phase III \\
\hline \multirow[t]{4}{*}{$\mathrm{NAA} / \mathrm{Cr}$} & VOI1 & $\begin{aligned} \text { Phase I } & =2.154 \pm 0.404 \\
\text { Phase II } & =1.798 \pm 0.288 \\
\text { Phase III } & =1.811 \pm 0.304\end{aligned}$ & $\begin{array}{c}\mathrm{F}(2,20)=3.771 \\
(p=0.041)\end{array}$ & Phase I > Phase II \\
\hline & $\mathrm{VOI} 1+\mathrm{VOI} 2$ & $\begin{aligned} \text { Phase I } & =2.126 \pm 0.444 \\
\text { Phase II } & =1.817 \pm 0.406 \\
\text { Phase III } & =1.857 \pm 0.268\end{aligned}$ & $\begin{array}{c}\mathrm{F}(2,42)=4.635 \\
\quad(p=0.015)\end{array}$ & Phase I > Phase II \\
\hline & VOI1 + VOI3 + VOI5 & $\begin{aligned} \text { Phase I } & =1.971 \pm 0.353 \\
\text { Phase II } & =1.811 \pm 0.332 \\
\text { Phase III } & =1.768 \pm 0.256\end{aligned}$ & $\begin{array}{c}\mathrm{F}(2,64)=3.685 \\
\quad(p=0.031)\end{array}$ & Phase I > Phase III \\
\hline & $\begin{array}{l}\text { VOI } 1+\text { VOI } 2+\text { VOI } 3+ \\
+ \text { VOI } 4+\text { VOI } 5+\text { VOI } 6\end{array}$ & $\begin{aligned} \text { Phase I } & =1.919 \pm 0.393 \\
\text { Phase II } & =1.781 \pm 0.339 \\
\text { Phase III } & =1.795 \pm 0.268\end{aligned}$ & $\begin{array}{l}\mathrm{F}(2,130)=3.644 \\
\quad(p=0.029)\end{array}$ & Phase I > Phase II \\
\hline $\mathrm{Glx} 1 / \mathrm{Cr}$ & VOI6 & $\begin{aligned} \text { Phase I } & =0.536 \pm 0.056 \\
\text { Phase II } & =0.417 \pm 0.111 \\
\text { Phase III } & =0.396 \pm 0.174\end{aligned}$ & $\begin{array}{l}\mathrm{F}(2,20)=4.104 \\
\quad(p=0.032)\end{array}$ & Phase I > Phase III \\
\hline $\mathrm{Glx} 2 / \mathrm{Cr}$ & VOI4 & $\begin{aligned} \text { Phase I } & =0.351 \pm 0.159 \\
\text { Phase II } & =0.496 \pm 0.175 \\
\text { Phase III } & =0.356 \pm 0.108\end{aligned}$ & $\begin{array}{l}\mathrm{F}(2,20)=7.591 \\
(p=0.004)\end{array}$ & Phase II > Phase I, III \\
\hline
\end{tabular}


tional impairment [28]. Because the group examined consisted of healthy women, all NAA differences found should be treated as the effect of functional changes in, for example, neurotransmission rather than fluctuations in the number of neurons.

The results obtained may be in accordance with the results presented by Rasgon [17]. He compared the $\mathrm{NAA} / \mathrm{Cr}$, Cho/ $\mathrm{Cr}$ and $\mathrm{mI} / \mathrm{Cr}$ ratios between the control group of healthy women and the group with premenstrual tension syndrome, in two locations: the longitudinal fissure, and the left occipital lobe, corresponding to the VOI6 location in this paper. The mean value of $\mathrm{NAA} / \mathrm{Cr}$ in the first examined location was found to be higher in the follicular phase in comparison to the luteal one, similarly to our study. However, in the second examined location Rasgon found a reverse tendency compared to the tendency suggested in this paper - lower NAA/Cr ratio at the start of the cycle in comparison with the late luteal phase. He also found a significant increase in mean $\mathrm{Cho} / \mathrm{Cr}$ ratios from the start of the cycle to the luteal phase. The authors observed no similar relationship based on their own results.

A higher mean $\mathrm{Glx} 1 / \mathrm{Cr}$ ratio in VOI6 was found in the initial phase of the cycle compared to the later ones. Moreover, a higher mean $\mathrm{Gl} 2 \mathrm{2} / \mathrm{Cr}$ ratio in VOI4 was found in phase II, corresponding to ovulation, compared to the others. Even Rasgon suggested that different hormonal levels (estrogen and progesterone) during the cycle may influence neurotransmission with the participation of glutamine and glutamate (Glx) [17]. Batra using a $3 \mathrm{~T}$ system, a non-standard electromagnetic field impulse sequence and a single VOI only, $2 \times 3 \times 3 \mathrm{~cm}$, located at the level of the frontal lobes in the longitudinal fissure, studied the difference between a control group of healthy women and a group with premenstrual tension syndrome [21]. He found significant fluctuations in glutamate level during the cycle (higher mean ratios in the follicular compared to the luteal phase). Because of the different techniques used, it would be difficult to compare the results obtained by Batra to ours. Nevertheless, the variability in glutamine and glutamate levels seems to confirm the hypothesis formulated in the publications discussed concerning the influence of female sex steroid fluctuations on neurotransmission with the participation of these brain metabolites.

In our research we observed no similar statistically significant GABA level fluctuations in any location assessed.

This is interesting, inasmuch as glutamate is recognized as a neurotransmitter with an antagonistic func- tion compared to GABA [21,29]. One should therefore expect fluctuations in mean $\mathrm{GABA} / \mathrm{Cr}$ ratios in different cycle phases, if fluctuations of mean $\mathrm{Gl} \times 1 / \mathrm{Cr}$ and $\mathrm{Glx} 2 / \mathrm{Cr}$ ratios were found. Epperson [18-20], using a system with a non-standard magnetic field induction of $2.1 \mathrm{~T}$, a specific procedure for GABA peak isolation and a single VOI of $1.5 \times 3 \times 3 \mathrm{~cm}$ in the occipital lobes, found that GABA level significantly fluctuates from higher to lower values in the follicular and luteal phases respectively in a control group of healthy women.

Recently, Harada [30], using a $3 \mathrm{~T}$ system and MEGA-editing J-difference technique, found GABA levels decreased in the luteal phase compared with the follicular phase in the lentiform nuclei and left frontal lobe, but not in the anterior cingulate cortex.

A raised $\mathrm{Lac} / \mathrm{Cr}$ ratio level most frequently indicates a pathological process related to anaerobic glycolysis $[13,28]$. Because of this, such a result should be related to the small size of the group rather than an authentic relation between menstrual cycle phase and physiological brain metabolism.

Finally, it should be mentioned that the influence of hormone fluctuation during the menstrual cycle on brain metabolism can now be assessed not only by ${ }^{1}$ HMRS, but also other imaging techniques such as functional magnetic resonance imaging (fMRI) or positron emission tomography (PET) $[31,32]$.

\section{Conclusions}

1. Statistically significant relations between menstrual cycle phases and relative ratios of selected metabolites in different brain locations were found in the present pilot study.

2. This is a basis for the need to take the patient's cycle phase into consideration during planning a date for ${ }^{1}$ HMRS examination and during interpretation of the results. It should particularly be considered during planned verification of any disease manifesting as $\mathrm{NAA} / \mathrm{Cr}, \mathrm{Glx} / \mathrm{Cr}$ or $\mathrm{Lac} / \mathrm{Cr}$ changes compared to a normal ${ }^{~} \mathrm{HMRS}$ spectrum.

3. The clinical usefulness of such a requirement should still be verified, based on a greater number of women, and not only healthy, but also those suffering from specific diseases.

\section{Disclosure}

Authors report no conflict of interest. 


\section{References}

1. Chabbert-Buffet N., Bouchard P. The normal human menstrual cycle. Rev Endocr Metab Disord 2002; 3: 173-183.

2. Smith S.S. Pre-menstrual steroids. Cell Mol Life Sci 2001; 58: 1263-1275.

3. Becù-Villalobos D., González Iglesias A., Díaz-Torga G., et al. Brain sexual differentiation and gonadotropins secretion in the rat. Cell Mol Neurobiol 1997; 17: 699-715.

4. Carrer H.F., Cambiasso M.J. Sexual differentiation of the brain: genes, estrogen and neurotrophic factors. Cell Mol Neurobiol 2002; 22: 479-500.

5. Nikolova P.P., Negrev N.N., Stoyanova Z., et al. Functional brain asymmetry, handedness and age characteristics of climacterium in women. Int J Neurosci 1996; 86: 143-149.

6. Nikolova P.P., Negrev N.N., Stoyanov P. Functional brain asymmetry, handedness and menarcheal age. Int J Psychophysiol 1994; 18: 213-215

7. Nikolova P.P., Negrev N.N., Nikolova R.I., et al. Menstrual rhythm, menstrual interval, and duration of menstruation in left-handed and right-handed women. Fiziol Cheloveka 2003; 29: $143-144$

8. Vasil'eva V.V. Spectra an coherent characteristics of EEG in women during various phases of menstrual cycle. Bull Exp Biol Med 2005; 140: 383-384.

9. Krukowski P., Podgórski P., Guziński M., et al. Analysis of the brain proton magnetic resonance spectroscopy - differences between normal grey and white matter. Pol J Radiol 2010; 75: 22-26.

10. Kołtowska A., Hendrich B., Knysz B., et al. Analysis of metabolic changes of brain in HIV-1 seropositive patients with proton magnetic resonance spectroscopy. Pol J Radiol 2010; 75: 27-32.

11. Kubas B., Łebkowski W., Łebkowska U., et al. Proton MR spectroscopy in mild traumatic brain injury. Pol J Radiol 2010; 75: 7-10.

12. Burlina A.P., Aureli T., Bracco F., et al. MR spectroscopy: a powerful tool for investigating brain function and neurological diseases. Neurochem Res 2000; 25: 1365-1372.

13. Talos I.F., Mian A.Z., Zou K.H., et al. Magnetic resonance and the human brain: anatomy, function and metabolism. Cell Mol Life Sci 2006; 63: 1106-1124.

14. Grachev I.D., Apkarian A.V. Multi-chemical networking profile of the living human brain: potential relevance to molecular studies of cognition and behavior in normal and diseased brain. J Neural Transm 2002; 109: 15-33.

15. Henning A., Schär M., Kollias S.S., et al. Quantitative magnetic resonance spectroscopy in the entire human cervical spinal cord and beyond at 3T. Magn Reson Med 2008; 59: 1250-1258.

16. De Stefano N., Filippi M., Miller D., et al. Guidelines for using proton MR spectroscopy in multicenter clinical MS studies. Neurology 2007; 69: 1942-1952.

17. Rasgon N.L., Thomas M.A., Guze B.H., et al. Menstrual cycle-related brain metabolite changes using $\mathrm{H}-1$ magnetic resonance spectroscopy in premenstrual women: a pilot study. Psychiatry Res 2001; 106: 47-57.
18. Epperson C.N., Gueorguieva R., Czarkowski K.A., et al. Preliminary evidence of reduce occipital GABA concentrations in puerperal women: a 1H-MRS study. Psychopharmacology 2006; 186: 425-433.

19. Epperson C.N., Haga K., Mason G.F., et al. Cortical $\gamma$-aminobutyric acid levels across the menstrual cycle in healthy women and those with premenstrual dysphoric disorder. Arch Gen Psychiatry 2002; 59: 851-858.

20. Epperson C.N., O’Malley S., Czarkowski K.A., et al. Sex, GABA, and nicotine: the impact of smoking on cortical GABA levels cross the menstrual cycle as measured with proton magnetic resonance spectroscopy. Biol Psychiatry 2005; 57: 44-48.

21. Batra A.N., Seres-Milo J., Hanstock Ch., et al. Proton magnetic resonance spectroscopy measurement of brain glutamate levels in premenstrual dysphoric disorder. Biol Psychiatry 2008; 63: $1178-1184$

22. Musso F., Bettermann F., Vucurevic G., et al. Smoking impacts on prefrontal attentional network function in young adult brains. Psychopharmacology 2007; 191: 159-169.

23. Braunová Z., Kasparowá S., Mlynárik V., et al. Metabolic changes in rat brain after prolonged etanol consumption measured by ${ }^{1} \mathrm{H}$ and ${ }^{31} \mathrm{P}$ MRS experiments. Cell Mol Neurobiol 2000; 20: 703-715.

24. Ende G., Walter S., Welzel H., et al. Alcohol consumption significantly influences the MR signal of frontal choline-containing compounds. Neuroimage 2006; 32: 740-746.

25. Follesa P., Biggio F., Talani G., et al. Neurosteroids, GABA receptors, and ethanol dependence. Psychopharmacology 2006; 186: 267-280

26. Meyerhoff D.J., Durazzo T.C. Proton magnetic resonance spectroscopy in alcohol use disorders: a potential new endophenotype? Alcohol Clin Exp Res 2008; 32: 1146-1158.

27. Nosenko N.D., Reznikov A.G. Sexual differentiation of the brain as a manifestation of its plasticity. Neurophysiol 2001; 2: 141-150.

28. De Stefano N., Filippi M., Miller D., et al. Guidelines for using proton MR spectroscopy in multicenter clinical MS studies. Neurology 2007; 69: 1942-1952.

29. Amin Z., Mason G.F., Cavus I., et al. The interaction of neuroactive steroids and GABA in the development of nueropsychiatric disorders in women. Pharmacol Biochem Behav 2006; 84: 635-643.

30. Harada M., Kubo H., Nose A., et al. Measurement of variation in the human cerebral GABA level by in vivo MEGA-editing proton MR spectroscopy using a clinical $3 \mathrm{~T}$ instrument and its dependence on brain region and the female menstrual cycle. Hum Brain Mapp 2011; 32: 828-833.

31. Protopopescu X., Tuescher O., Pan H., et al. Toward a functional neuroanatomy of premenstrual dysphoric disorder. $J$ Affect Disord 2008; 108: 87-94.

32. Rapkin A.J., Berman S.M., Mandelkern M.A., et al. Neuroimaging evidence of cerebellar involvement in premenstrual dysphoric disorder. Biol Psychiatry 2011; 69: 374-380. 